\begin{tabular}{|c|c|}
\hline Title & Effects of $Y$-hexachlorocy clohexane on apoptosis induced by serum deprivation in PC12 cells \\
\hline Author(s) & A oki, Kentaro; Egawa, Mari; Saito, T akeshi; Hosokawa, Toshiyuki; Kurasaki, Masaaki \\
\hline Citation & $\begin{array}{l}\text { Journal of Environmental Science and Health, Part B : Pesticides, Food Contaminants, \& A gricultural Wastes, 43(6), } \\
\text { 471-475 } \\
\text { https://doi.org/10.1080/03601230802174573 }\end{array}$ \\
\hline Issue Date & $2008-08$ \\
\hline Doc URL & http:/hdl.handle.net/2115/47396 \\
\hline Rights & $\begin{array}{l}\text { This is a preprint of an article submitted for consideration in the Journal of Environmental Science and Health, Part B } \\
\text { @ 2008 Taylor \& Francis. Journal of Environmental Science and Health, Part B is available online at: } \\
\text { www.tandfonline.com. }\end{array}$ \\
\hline Type & article (author version) \\
\hline File Information & A okiJESH3.pdf \\
\hline
\end{tabular}

Instructions for use 


\section{Effects of $\gamma$-hexachlorocyclohexane on apoptosis induced by serum deprivation in PC12 cells}

KENTARO, AOKI $^{1}$, MARI, EGAWA ${ }^{1}$, TAKESHI, SAITO $^{2}$, TOSHIYUKI, HOSOKAWA ${ }^{3}$ and MASAAKI, KURASAKI ${ }^{1,4 *}$

${ }^{1}$ Department of Environmental Remediation, Graduate School of Environmental Science, Hokkaido University, Sapporo, Japan

${ }^{2}$ Department of Health Sciences, Hokkaido University School of Medicine, Sapporo, Japan

${ }^{3}$ Center for $R$ \& $D$ in Higher Education, Hokkaido University,

Sapporo, Japan

${ }^{4}$ Department of Integral Environmental Science, Faculty of Environmental Earth Science, Hokkaido University, Sapporo,

\footnotetext{
* Address correspondence to Masaaki, KURASAKI,

Faculty of Environmental Earth Science, Hokkaido University

Sapporo 060-0810, Japan; Phone:+81-11-706-2243,Fax:

+81-11-706-4864;E-mail:kura@ees.Hokudai.ac.jp
} 
Japan

\section{ABSTRACT}

The effects of $\gamma$-hexachlorocyclohexane, one of the endocrine disrupters, widely used for agricultural and medicinal purpose, on apoptosis in PC12 cells were investigated using western blotting analysis and RT-PCR method. Apoptosis is a fundamental process necessary for development of individuals and organs. Although $\gamma-\mathrm{HCH}$ at high concentration did not effect on cell viability and apoptosis, DNA fragmentation was slightly enhanced, and apoptotic factors; Bax, Bad, cytochrome c and caspase-3 showed tendency of increase by addition of low $\gamma-\mathrm{HCH}$ to the cell medium. However these changes were not statistically significant. It was concluded that $\gamma-\mathrm{HCH}$ did not affect on apoptosis in the PC12 cell line system, although $\gamma-\mathrm{HCH}$ has been reported to induce apoptosis 
in other cell lines.

Keywords: apoptosis, $\gamma-\mathrm{HCH}, \mathrm{PC} 12$ cell, caspase, cytochrome C, Bc1-2 family

\section{INTRODUCTION}

$1,2,3,4,5,6$-hexachlorocyclohexane $(\mathrm{HCH})$ is widely used for agricultural and medicinal purpose. Mixtures of $\mathrm{HCH}$ isomers have been used extensively since the 1940 s to control malaria mosquitoes, and an isomer of $\mathrm{HCH}$ is still used in the USA as a component of pediculicide shampoos for head lice and scabies, [1] but in many countries it is banned for public use. Technical graded $\mathrm{HCH}$ is eight stereoisomers $(\alpha, \beta, \gamma, \sigma, \varepsilon, 1,0, \eta)$. Lindane, the $\gamma$-isomer possesses the most significant insecticidal activity. [2] $\gamma-\mathrm{HCH}$ is the most persistent and, therefore, accumulative isomer whilst the $\alpha$-and $\gamma$-isomer are mostly converted into the $\beta$-isomer in biological systems. ${ }^{[3]}$ However, usage of the $\alpha$-and $\beta$-isomers has fallen more rapidly than that of lindane itself. [4] 
The primary route of $\mathrm{HCH}$ exposure in the general population is through dietary intake ${ }^{[5]}$ particularly via meat and dairy products. [6] $\mathrm{HCH}$ has been reported to induce reproductive toxicities in rat including decrease in sexual receptivity, ${ }^{[7]}$ and induction of degenerative changes in seminiferous tubules. In such animal models lindane-induced damage may result from the generation of superoxide anion radicals, and/or DNA single-strand breaks and epigenetic mechanisms. ${ }^{[8]}$

On the other hand, it has been reported that some of endocrine disrupters act as chemical substances caused apoptosis in cells. [9-13] In addition, $\gamma-\mathrm{HCH}$ induced apoptosis in HL-60 cells through intracellular Ca2+ release pathway. ${ }^{[14]}$ Apoptosis is a kind of physiological cell death that plays a key role in the maintenance of homeostasis of various animal species. ${ }^{[15]}$ Apoptotic cell death is characterized by chromatin condensation, DNA fragmentation, and cellular shrinkage resulted in the formation of apoptotic bodies. [15]

Apoptosis is mediated by member of caspase family of proteases 
and eventually causes the degradation of chromosomal DNA. [16] The effector caspase represented by caspase-3 is frequently activated in response to various apoptosis inducers and essential for the execution and completion of apoptosis in many, but not all, cell types or death stimuli. Pathways leading to activation of the effector caspase have been identified to be either dependent or independent on the release of cytochrome c from mitochondria into the cytosol. ${ }^{[17,18]}$ In addition, activation of the effector caspase appears to be tightly regulated by a signaling mechanism including the members of Bcl-2 family, ${ }^{[18]}$ which include pro-apoptotic proteins such as Bax and Bad is induced the mitochondrial cytochrome c release. ${ }^{[19]}$

PC12 is a rat pheochromocytoma clonal cell line that responds to nerve growth factor by extending neurites, thus acquiring the appearance of neurons. ${ }^{[20]}$ Over the past 30 years, PC12 cells have become a very suitable model to study neuronal function and differentiation. ${ }^{[21]}$ In this study, to understand the neuronal damage of endocrine disrupters such as $\gamma-\mathrm{HCH}$, effects of $\gamma-\mathrm{HCH}$ on apoptosis induced by serum deprivation in PC12 cells were 
investigated. Experiments were conducted at low-dose and high-dose concentrations of $\gamma-\mathrm{HCH}$ to study the effect of the chemical substance.

\section{MATERIALS AND METHODS}

\section{Materials}

PC12 cells, a cell line of rat pheochromocytoma cells, were purchased from the American Type Culture Collection (USA and Canada). Dulbecco's modified Eagle's medium (DMEM) and $o$-phenylendiamine dihydrochloride (OPD) were obtained from Sigma (St. Louis, MO USA). Fetal bovine serum (FBS) was bought from HyClone (Rockville, MD USA). Caspase assay kit and SV total RNA isolation system were from Promega (Madison, WI USA). Trypan blue stain solution $(0.5 \%)$ and $1,2,3,4,5,6-\mathrm{Hexachlorocyclohexane}(\gamma-\mathrm{HCH})$ were from Nacalai Tesque (Kyoto, Japan). Biotin-16-2'-deoxy-uridine-5-triphosphate, proteinase $\mathrm{K}$ and the blocking reagent were from Roche Diagnostics (Mannheim, Germany). Terminal deoxynucleotidyl 
transferase (TdT) was from Toyobo (Osaka, Japan). Biotinylated anti-mouse immunoglobulin was from Amersham Pharmacia Biotech (Buckinghamshire, UK). Antibody of cytocrome c was purchased from Promega (Madison, WI USA). Other chemicals were of analytical regent grade.

\section{Cell Culture}

PC12 cells were maintained in DMEM supplemented with $10 \%$ FBS in a humidified incubator at $37^{\circ} \mathrm{C}$ and $5 \% \mathrm{CO}_{2}$. The cells were preincubated in $25 \mathrm{~cm}^{2}$ flasks for over night, and then the medium was replaced with serum/serum-free DMEM with or without $\gamma-\mathrm{HCH}$. When the medium was changed to serum deprivated medium, cells in the flask were washed twice with serum-free DMEM.

\section{Cell Viability Measured by Trypan Blue Exclusion Assay}

PC1 2 cells were incubated in the serum/serum-free medium with 0 to $5,000 \mathrm{ng} / \mathrm{mL} \gamma-\mathrm{HCH}$ for $72 \mathrm{hr}$. After the incubation, cells were stained in $0.25 \%$ trypan blue solution in phosphate-buffered saline. 
Total cells and trypan blue staining cells were counted by a hemocytometer. Cell viabilities were expressed as percentage against the total cell number in each experiment.

Quantification of DNA Fragmentation in PC12 Cells by the TdTMediated dUTP-biotin Nick End Labeling (TUNEL) Method

After that the PC12 cells were cultured in the serum/serum-free medium with 0 to $5,000 \mathrm{ng} / \mathrm{mL} \gamma-\mathrm{HCH}$ for 6 to $72 \mathrm{hr}$, genomic DNA was isolated by the method of Yamanoshita et al. [11] The obtained DNA was resuspended in $1 X$ TBE buffer and equal amount of DNA was put into 96-well plate wells. Quantification of DNA fragmentation in PC12 cells was measured by the method of Kurasaki et al. ${ }^{[22]}$ In briefly, the plate was incubated at $4{ }^{\circ} \mathrm{C}$ for over night. After the incubation, the plate was washed with the 40 $\mathrm{mM}$ Tris-HCl buffer, $\mathrm{pH} 7.4$, containing $150 \mathrm{mM} \mathrm{NaCl}$. Nonspecific binding sites were blocked with $2 \%$ blocking reagent in the same buffer for $30 \mathrm{~min}$. Then the plate was washed twice with same buffer. TdT reaction was performed in a reaction mixture consisting of $30 \mathrm{mM}$ Tris-HCl buffer, $\mathrm{pH} 7.4$, containing $140 \mathrm{mM}$ 
sodium cacodylate, $1 \mathrm{mM}$ cobalt chloride, 0.1 units $\mathrm{TdT} / \mu \mathrm{L}$ and 2 $\mathrm{nM}$ biotinylated-dUTP at $37^{\circ} \mathrm{C}$ for $1.5 \mathrm{hr}$. After the reaction, the plate was washed. The plate was incubated with streptavidin-conjugated peroxidase for $1 \mathrm{hr}$. After washing, $0.1 \%$ OPD in $50 \mathrm{mM}$ phosphate-citrate buffer, pH 5.0, containing $0.03 \%$ sodium perborate was added to each well and incubated for $0.5 \mathrm{hr}$ at $37{ }^{\circ} \mathrm{C}$. Then, $\mathrm{HCl}$ was added to stop the enzyme reaction. Absorbance at $495 \mathrm{~nm}$ was measured with a Microplate Reader model 450 (BIO-RAD).

\section{Gene Expression Determined by Reverse Transcriptase Chain Reaction (RT-PCR)}

The PC12 cells were incubated with 0 to $100 \mathrm{ng} / \mathrm{mL} \gamma-\mathrm{HCH}$ for $6 \mathrm{hr}$.

The total RNA of these cells was extracted using the SV total RNA isolation kit according to the instruction manual. The obtained total RNA was verified using a RNA 6000 nano assay with the Agilent 2100 bio analyzer according to the instruction manual. Expression of Bad, bax and bcl-2 mRNA was detected using the access RT-PCR kit and access RT-PCR introductory kit according 
to the instruction manual. Total RNA of PC12 cells cultured in the serum/serum-free medium with 0 to $100 \mathrm{ng} / \mathrm{mL} \gamma-\mathrm{HCH}$ for $6 \mathrm{hr}$ was prepared by using of SVTotal RNA Isolation kit. The PCR primers of Bad, Bax, Bcl-2 and $\beta$-actin were synthesized according to the their DNA sequences. PCR condition was as follows; $48^{\circ} \mathrm{C}$ for 45 $\min , 94^{\circ} \mathrm{C}$ for $2 \mathrm{~min}$. The cycles were $94^{\circ} \mathrm{C}$ for $30 \mathrm{~s}, 60^{\circ} \mathrm{C}$ for $1 \mathrm{~min}$, and $68^{\circ} \mathrm{C}$ for $2 \mathrm{~min}$. Final extension was for $7 \mathrm{~min}$ at $72^{\circ} \mathrm{C}$. The cycles performed were 30 or 40 . An annealing temperature of $60^{\circ} \mathrm{C}$ was used for $\beta$-actin and $\mathrm{Bax}, 55^{\circ} \mathrm{C}$ for $\mathrm{Bad}$, and $47^{\circ} \mathrm{C}$ for $\mathrm{Bcl}-2$. PCR of $\beta$-actin that was chosen as an internal control. PCR products were verified using a DNA 7500 assay with an Agilent 2100 Bio Analyzer according to the instruction manual.

\section{Western Blot Analysis Using Antibodies Against Cytochromec.}

The PC12 cells were cultured in the serum/serum-free medium with 0 to $100 \mathrm{ng} / \mathrm{mL} \gamma-\mathrm{HCH}$ for $6 \mathrm{hr}$. The same protein amounts of the obtained lysate were separated by polyacrylamide gel electrophoresis, and transferred to nitrocellulose membranes with a semidry blotting system type-AE6678 (ATTO, Japan). After 
transfer, the membranes were incubated for $2 \mathrm{hr}$ at room temperature with against cytochrome c antibodies in $40 \mathrm{mM}$ Tris-HCl buffer, $\mathrm{pH} 7.4$, containing $150 \mathrm{mM} \mathrm{NaCl}$ and $1 \%$ blocking reagent ( $1 \%$ blocking buffer). The membranes were washed three times for each $3 \mathrm{~min}$ in TBTS consisting of $40 \mathrm{mM}$ Tris-HCl buffer, $\mathrm{pH} 7.4,150 \mathrm{mM} \mathrm{NaCl}, 0.3 \%$ Tween 20 , and then incubated at room temperature for $1 \mathrm{hr}$ with anti-mouse IgG biotinylated secondary antibody (dilution; $1: 1000$ ) in the 1\% blocking buffer. The membranes were washed three times in TBTS and were washed twice for each 3 min in Tris-HCl buffer of $40 \mathrm{mM}$ Tris-HCl, pH 7.4, $150 \mathrm{mM} \mathrm{NaCl}$. Finally, streptavidin-conjugated peroxidase ( $1: 400$ diluted with the same buffer) was added and incubated for $1 \mathrm{hr}$. Protein bands responded to antibodies were detected with an enhanced chemiluminescence system.

\section{The Activity of Caspase-3-like Protease}

The activity of caspase-3-like protease was detected using the caspase assay system kit according to the instruction manual. This kit was using DEVD-pNA as substrate and this chemical was 
cleaved by DEVDase such as caspase-3 protease. The activity of caspase-3 like protease in the PC12 cells was indirectly measured as absorbance at $405 \mathrm{~nm}$ deputing on released pNA from the cleaved substrate. The caspase-3 like activity was expressed as relative contents against that in the cells incubated in the medium containing serum without $\gamma-\mathrm{HCH}$.

\section{Statistical Analysis}

Each value is expressed as mean \pm SEM. Statistical analyses were performed by one-way analysis of variance (ANOVA), followed by the Fisher's multi comparison test.

\section{RESULTS AND DISCUSSION}

To confirm whether $\gamma$-HCH affects on cell viability, the viability was measured by trypan blue staining after PC 12 cells exposed to 0 to $5,000 \mathrm{ng} / \mathrm{mL} \gamma-\mathrm{HCH}$ for $72 \mathrm{hr}$. No significant difference of viabilities among the cells exposed to 0 to $5,000 \mathrm{ng} / \mathrm{mL} \gamma-\mathrm{HCH}$ was observed (data not shown). These results indicated that $\gamma$-HCH did 
not show cytotoxicity against the PC12 cells.

With TUNEL method, DNA ends generated by endonucleases activity are specifically labeled. ${ }^{[23]}$ Quantification of DNA ladder was carried out to evaluate the degree of apoptosis in the cells treated with 0 to $5,000 \mathrm{ng} / \mathrm{mL} \gamma-\mathrm{HCH}$. As shown in Fig. $1 \mathrm{a}$, TUNEL signals were not significantly different between PC12 cells with and without $\gamma-\mathrm{HCH}(100$ to $5,000 \mathrm{ng} / \mathrm{mL})$. On the other hand, as shown in Fig. 1b, there is a tendency of increase $(p<0.1)$ in the DNA fragmentation in PC12 cells exposed with $10 \mathrm{ng} / \mathrm{mL} \gamma-\mathrm{HCH}$ as compared with that in control cells. From these results, there is a possibility of enhancement of the apoptosis in PC12 cells by addition of $\gamma-\mathrm{HCH}$ at low concentration. To examine weather $\gamma-\mathrm{HCH}$ enhances apoptosis induced by serum deprivation in PC12 cells, apoptotic factors such as Bcl-2 family, cytochrome c and caspase-3 were measured.

As shown in Fig. 2, contents of Bax and Bad mRNAs in the cells exposed with $\gamma$-HCH did not increase significantly as compared with those in the control PC12 cells (Fig. 2). In addition, from the 
results of western blotting analyses using the cell lysis from PC12 cells treated with $\gamma-\mathrm{HCH}$ was performed using antibodies against cytochrome c, the contents of cytochrome c was slightly increased in comparison with that in cells treated without $\gamma-\mathrm{HCH}$ (Fig. 3). Although Liu et al. ${ }^{[24]}$ reported that apoptosis is induced by releasing cytochrome c from mitochondria to cytosol, the amounts of cytochrome c in our experiment was not significantly increased by addition of $\gamma-\mathrm{HCH}$ as expected $(\mathrm{p}>0.1, \mathrm{n}=3)$.

Moreover, by addition of $\gamma-\mathrm{HCH}$, the caspase-3 like activity in the cells incubated in the serum/serum-free medium did not also increase (Fig. 4).

In this study, the DNA fragmentation under the apoptotic condition was slightly enhanced by the treatment with $\gamma-\mathrm{HCH}$ at low concentration (Fig. 1), although significant difference was not observed in cell viability and DNA fragmentation at high concentration (100-5,000 $\mathrm{ng} / \mathrm{mL} \gamma-\mathrm{HCH})$ in the PC12 cells.

It has been reported that serum deprivation induced apoptosis 
accompanied by rapid down-regulation of Bcl-2, and up-regulation of Bax and Bad. ${ }^{[24]}$ However, as shown in Fig. 2, the Bax and Bad mRNA contents were not changed in PC12 cells treated with $\gamma-\mathrm{HCH}$. Cytochrome c released into the cytosol activates the caspase cascade, and was generated during apoptosis from procaspase-3. [25] In this study, although content of cytochrome c was slightly increased in the cells cultured in the serum-free medium contains low concentration of $\gamma-\mathrm{HCH}$, the caspase-3 like activity did not increase under the same condition (Figs. 3 and 4). As results, it was concluded that $\gamma-\mathrm{HCH}$ affected on apoptosis induced by serum deprivation in the PC12 cells.

Kang et al. ${ }^{[14]}$ reported that $\gamma-\mathrm{HCH}$ at high concentration induced apoptosis in HL-60 cells through intracellular Ca ion release pathway. In addition $\gamma-\mathrm{HCH}$ was shown as an inhibiter of gap junction formation through apoptotic pathway. ${ }^{[26]}$ These reports dose not agree with this study. The reason of the discrepancy is still unknown. However these phenomena depend on the characteristics of the cell type. PC12 cells were used to study neuronal function and differentiation. It was suggested that a 
neuronal cell had a resistance against the toxic substances such as pesticide.

On the other hand, $\gamma-\mathrm{HCH}$ is thought as one of the endocrine disrupters. We had reported the relationship between the endocrine disrupters and apoptosis. Tributyltin and 2,4,5

Trichlorophenoxyacetic acid inhibited completely apoptosis induced by serum deprivation. ${ }^{[11,12]}$ Aoki et al. ${ }^{[13]}$ reported that nonylphenol enhanced apoptosis induced by serum deprivation.

Apoptosis is a fundamental process necessary for development of individuals and organs, and differentiation of the nervous system. [27] Since apoptosis is essential for cells in development and in elimination of harmful cells, the adverse effects of endocrine disrupting chemicals on apoptosis would cause serious damages to organisms. ${ }^{[28]}$ According to this study and our previous reports, it was suggested that the effect of endocrine disrupters on apoptosis was independent from the reaction of estradiol receptor.

Therefore, the methods presented in this study, are expected to be a 
useful tool for evaluating of endocrine disrupting chemicals which dose not only relate to disrupt endocrine function by the binding to the estrogen receptor, but also relate to affect on the other functions such as apoptosis.

\section{REFEREN CES}

[1] Meinking, T.L.; Serrano, L.; Hard, B.; Entzel, P.; Lemard, G.; Rivera, E.; Villar, M.E. Comparative in vitro pediculicidal efficancy of treatments in a resistant head lice population in the United States. Arch. Dermato1. 2002, 38, 220-224.

[2] Xi, Y.L.; Chu, Z.X.; Xu, X.P. Effect of four organochlorine pesticides on the reproduction of freshwater rotifer Brachionus calyciflorus Pallas. Environ. Toxicol. Chem. 2007, 26, $1695-1699$.

[3] Jensen, A.A.; Slorach, S.A. Chemical contaminants in human 
milk. Boca Raton Ann Arbor Boston: CRC Press Inc. 1991.

[4] Breivik, K.; Pacyna J.M.; Munch, J. Use of $\alpha$-, $\beta$-and $\gamma$-hexachlorocyclohexane in Europe, 1970-1996. Sci. Total Environ. 1999, 239, $151-163$.

[5] DeVoto, E.; Kohlmeier, L.; Heeschen, W. Some dietary predictors of plasma organochlorine concentrations in an elderly German population. Arch. Environ. Health 1998, 53, $147-155$.

[6] Thomas, G.O.; Sweetman, A.J.; Jones, K.C. Metabolism and body-burden of PCBs in lactating dairy cows. Chemosphere 1999, 39, $1533-1544$.

[7] Uphouse, L. Decreased rodent sexual receptivity after lindane. Toxicol. Lett. 1987, 39, 7- 14 .

[8] Sagelsdorff, P.; Lutz, W.K.; Schlatter, C. The relevance of covalent binding to mouse liver DNA to the carcinogenic 
action of hexachlorocyclohexane isomers. Carcinogenesis $\mathbf{1 9 8 3}$, $4,1267-1273$.

[9] Aw, T.Y.; Nicotera, P.; Manzo, L.; Orrenius, S. Tributyltin stimulates apoptosis in rat thymocytes. Arch. Biochem. Biophys. 1990, 283, 46-50.

[10] Hughes, P.J.; McLellan, H.; Lowes, D.A.; Kahn, S.Z.; Bilmen, J.G.; Tovey, S.C.; Godfrey, R.E.; Michell, R.H.; Kirk, C.J.; Michelangeli, F. Estrogenic alkylphenols induce cell death by inhibiting testis endoplasmic reticulum $\mathrm{Ca}\left({ }^{2+}\right)$ pumps. Biochem. Biophys. Res. Commun. 2000, 277, 568-574.

[11] Yamanoshita, O.; Kurasaki, M.; Saito, T.; Takahasi, K.; Sasaki, H.; Hosokawa, T.; Okabe, M.; Mochida, J.; Iwakuma, T. Diverse effect of tributyltin on apoptosis in PC12 cells. Biochem. Biophys. Res. Commun. 2000, 272, 557-562.

[12] Yamanoshita, O.; Saito, T.; Takahashi, K.; Hosokawa, T.; 
Okabe, M.; Ito, K.; Kurasaki, M. 2,4,5-Trichlorophenoxyacetic acid inhibit apoptosis in PC12 cells. Life Sci. 2001, 69, $403-408$.

[13] Aoki, M.; Kurasaki, M.; Saito, T.; Seki, S.; Hosokowa, T.; Takahashi, Y.; Fujita, H.; Iwakuma, T. Nonylphenol enhances apoptosis induced by serum deprivation in PC12 cells. Life Sci. $\mathbf{2 0 0 4}, 74,2301-2312$.

[14] Kang, J.J.; CHEN, I.L.; YEN-YANG, H.F. Mediation of $\gamma$-Hexachlorocyclohexane-induced DNA Fragmentation in HL-60 Cells through Intracellular $\mathrm{Ca}^{2+}$ Release Pathway. Food Chem. Toxicol. 1998, 36, 513-520.

[15] Kerr, J.F.; Wyllie, A.H.; Currie, A.R. Apoptosis: a basic biological phenomenon with wide-ranging implications in tissue kinetics. Br. J. Cancer 1972, 26, 239-257.

[16] Enari, M.; Sakahira, H.; Yokoyama, H.; Okawa, K.; Iwamatsu, 
A.; Nagata, S. A caspase-activated DNase that degrades DNA during apoptosis, and its inhibitor ICAD. Nature 1998, 391, $43-50$.

[17] Green, D.R.; Reed, J.C. Mitochondria and apoptosis. Science 1998, 281, 1309-1312.

[18] Hatai, T.; Matsuzawa, A.; Inoshita, S.; Mochida, Y.; Kuroda, T.; Sakamaki, K.; Kuida, K.; Yonehara, S.; Ichijo, H.; Takeda, K. Execution of apoptosis signal-regulating kinase 1 (ASK1)-induced apoptosis by the mitochondria-dependent caspase activation. J. Biol. Chem. 2000, 275, 26576-26581.

[19] Francois, F.; Godinho, M.J.; Dragunow, M.; Grimes, M.L. A population of PC12 cells that is initiating apoptosis can be rescued by nerve growth factor. Mol. Cell. Neurosci. 2001, 18, 347-362.

[20] Greene, L.A.; Tischler, A.S. Establishment of a noradrenergic 
clonal line of rat adrenal pheochromocytoma cells which respond to nerve growth factor. Proc. Natl. Acad. Sci. USA 1976, 73, 2424-2428.

[21] Ravni, A.; Bourgault, S.; Lebon, A.; Chan, P.; Galas, L.; Fournier, A.; Vaudry, H.; Gonzalez, B.; Eiden, L.E.; Vaudry, D. The neurotrophic effects of PACAP in PC12 cells: control by multiple transduction pathways. J. Neurochem. 2006, 98, $321-329$.

[22] Kurasaki, M.; Aoki, M.; Miura, T.; Seki, S.; Toriumi, S.; Hosokawa, T.; Okabe, M.; Numata, T.; Saito, S.; Saito, T. A developed method of Terminal deoxynucleotidyl transferase system for quantification of DNA damage caused by apoptosis. Anal. Sci. 2001, 17(Suppl), i1547-i1550.

[23] Gollapudi, L; Oblinger, M.M. Stable transfection of PC12 cells with estrogen receptor $(\operatorname{ER} \alpha)$. protective effects of 
estrogen on cell survival after serum deprivation. J. Neurosci.

Res. 1999, 56, 99-108.

[24] Liu, X.; Zhu, X.Z. Roles of p53, c-myc, Bcl-2, Bax and caspases in serum deprivation-induced neuronal apoptosis: A possible neuroprotective mechanism of basic fibroblast growth factor. NeuroReport 1999, 10, 3087-3091.

[25] Banasiak, K.J.; Xia, Y.; Hanada, G.G. Mechanisms underlying hypoxia-induced neuronal apoptosis. Prog. Neurobiol. 2000,62, 215-249.

[26] Li, R.; Mather, J.P. Lindane, an inhibitor of gap junction formation, abolishes oocyte directed follicle organizing activity in vitro. Endocrinology 1997, 138, 4477-4480.

[27] Bredesen, D.E. Neural apoptosis. Ann. Neurol. 1995, 38, 839-851.

[28] Saito, T.; Kurasaki, M. Apoptosis and endocrine disrupters. 
Biomed. Res. 2000, 21, 353-359.

\section{FIGURE LEGENDS}

Fig. 1 Relative contents of DNA fragmentation in PC 12 cells treated with $\gamma-\mathrm{HCH}: 0$ to $5000 \mathrm{ng} / \mathrm{mL}$ (a), 0 to $100 \mathrm{ng} / \mathrm{mL}$ (b) in serum-containing medium or serum-free medium, for $72 \mathrm{hr}$. Error bars indicate $\operatorname{SEM}(a: n=6, b: n=3)$.

Fig. 2 Relative contents of Bax mRNA (a) and BadmRNA (b) in PC1 2 cells treated with $\gamma-\mathrm{HCH}(0$ to $100 \mathrm{ng} / \mathrm{mL})$ in serum-containing medium or serum-free medium for $6 \mathrm{hr}$. Error bars indicate SEM $(n=3)$.

Fig.3 Western blot analyses of cytochrome c in PC 12 cells treated with $\gamma-\mathrm{HCH}(0$ to $100 \mathrm{ng} / \mathrm{mL})$ in serum-containing medium 
or serum-free medium for $6 \mathrm{hr}$.

Fig. 4 Relative contents of Caspase-3 in PC 12 cells treated with $\gamma$-HCH (0 to $100 \mathrm{ng} / \mathrm{mL})$ in serum-containing medium or serum-free medium for $6 \mathrm{hr}$. Error bars indicate SEM $(n=3)$. 
a)

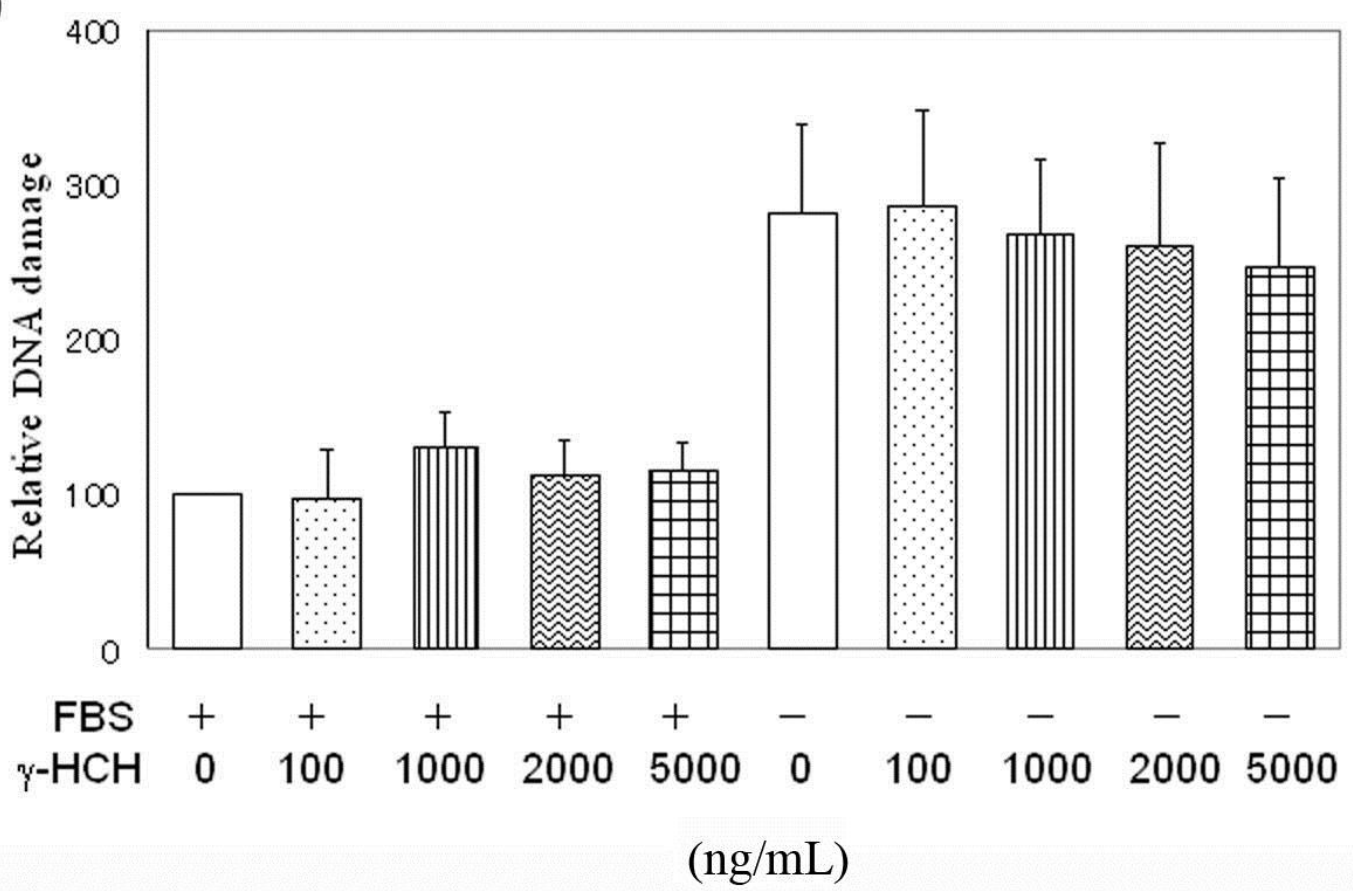

b)

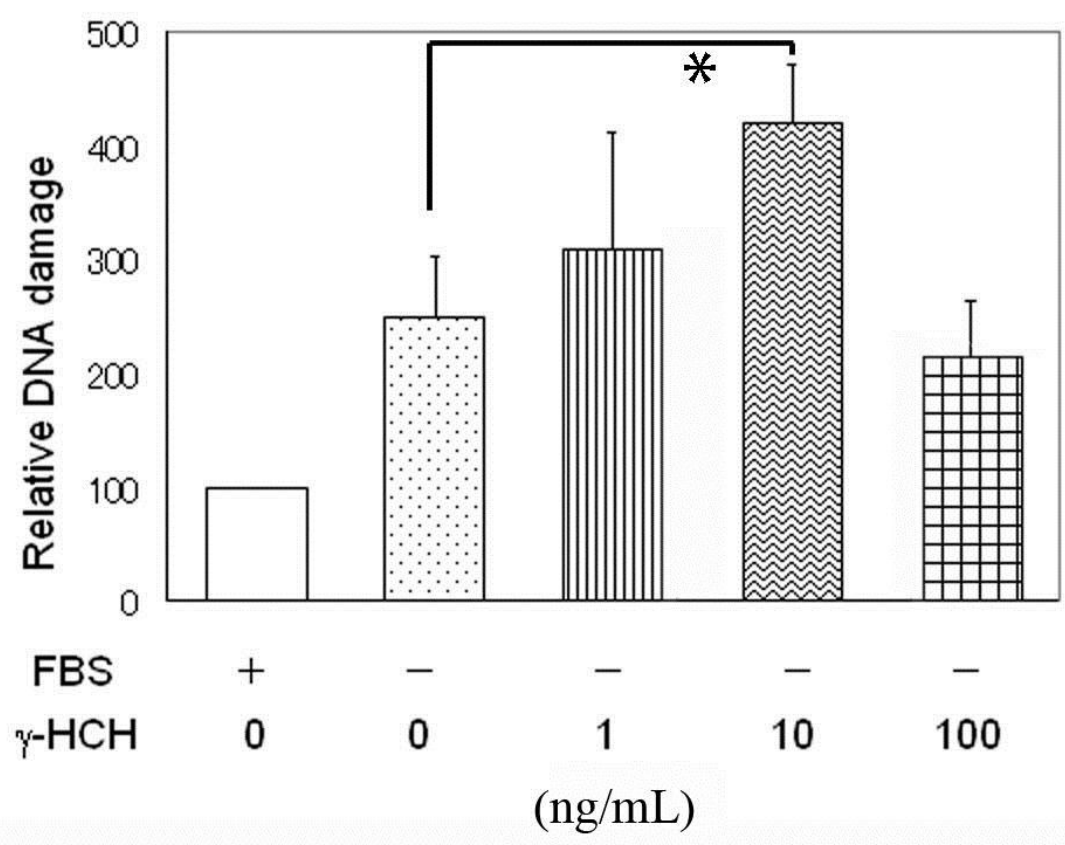

Fig.1 
a)
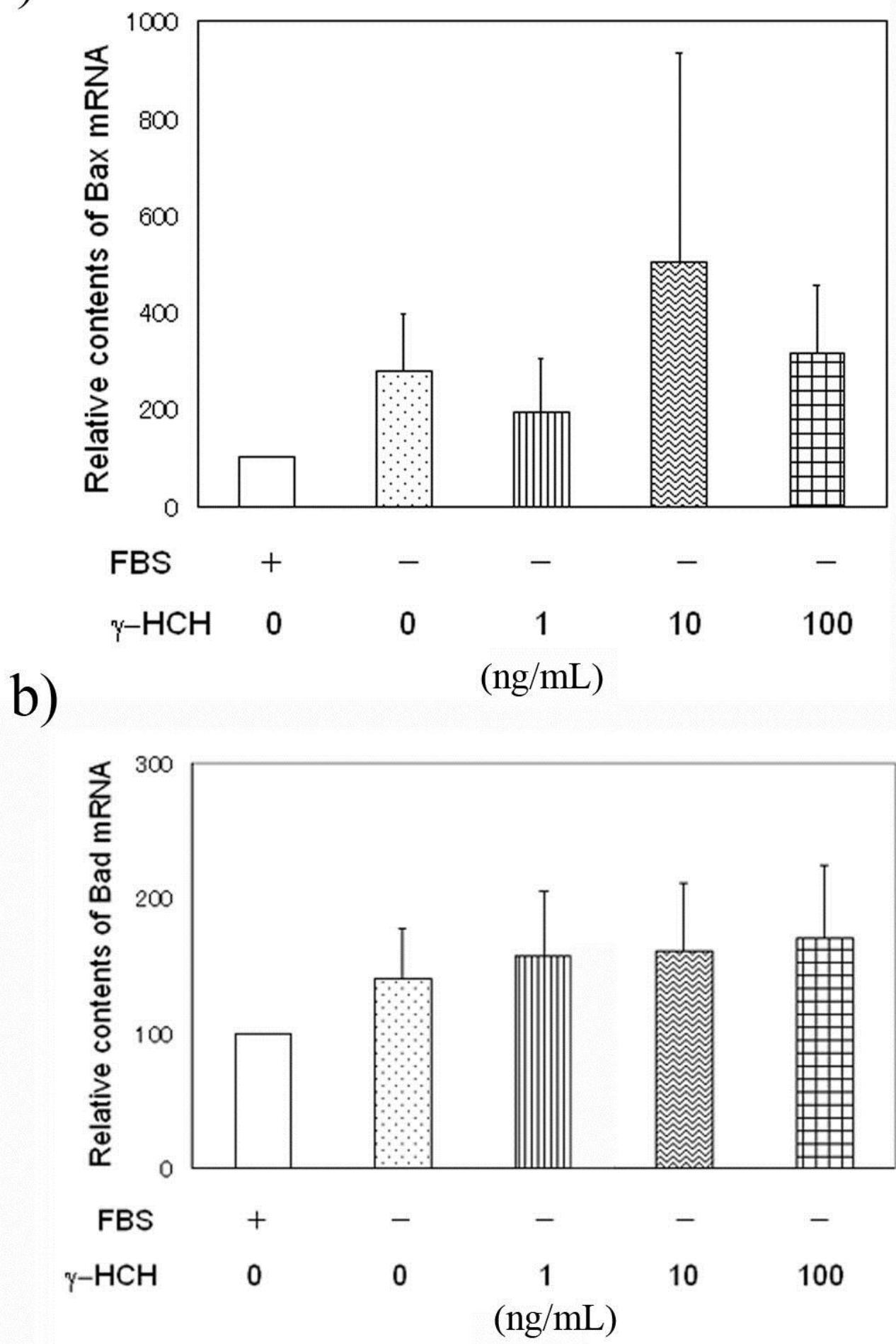

Fig. 2 


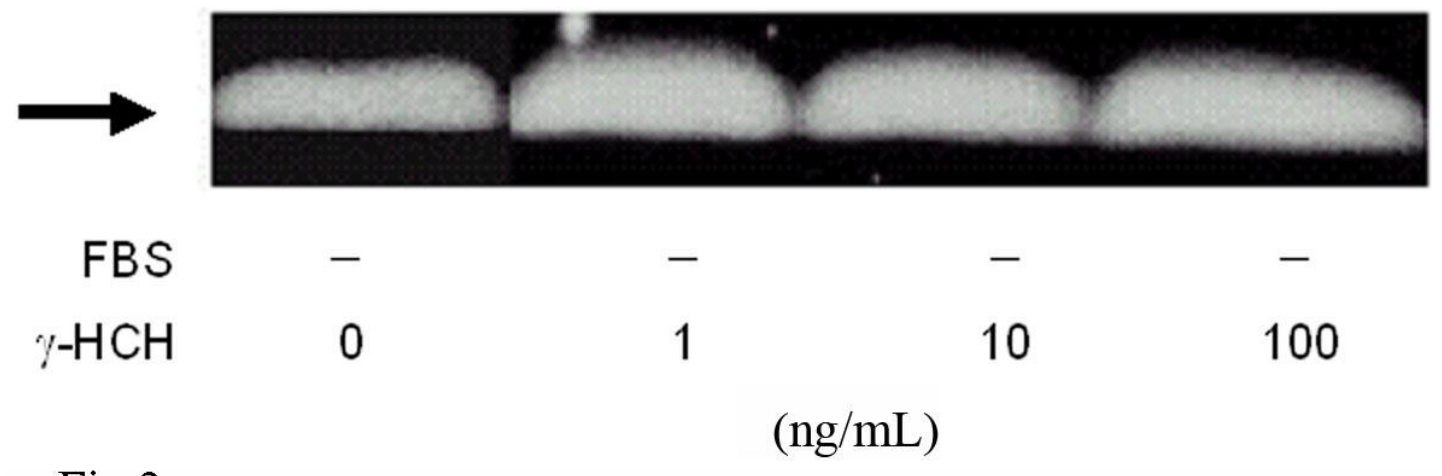

Fig. 3 


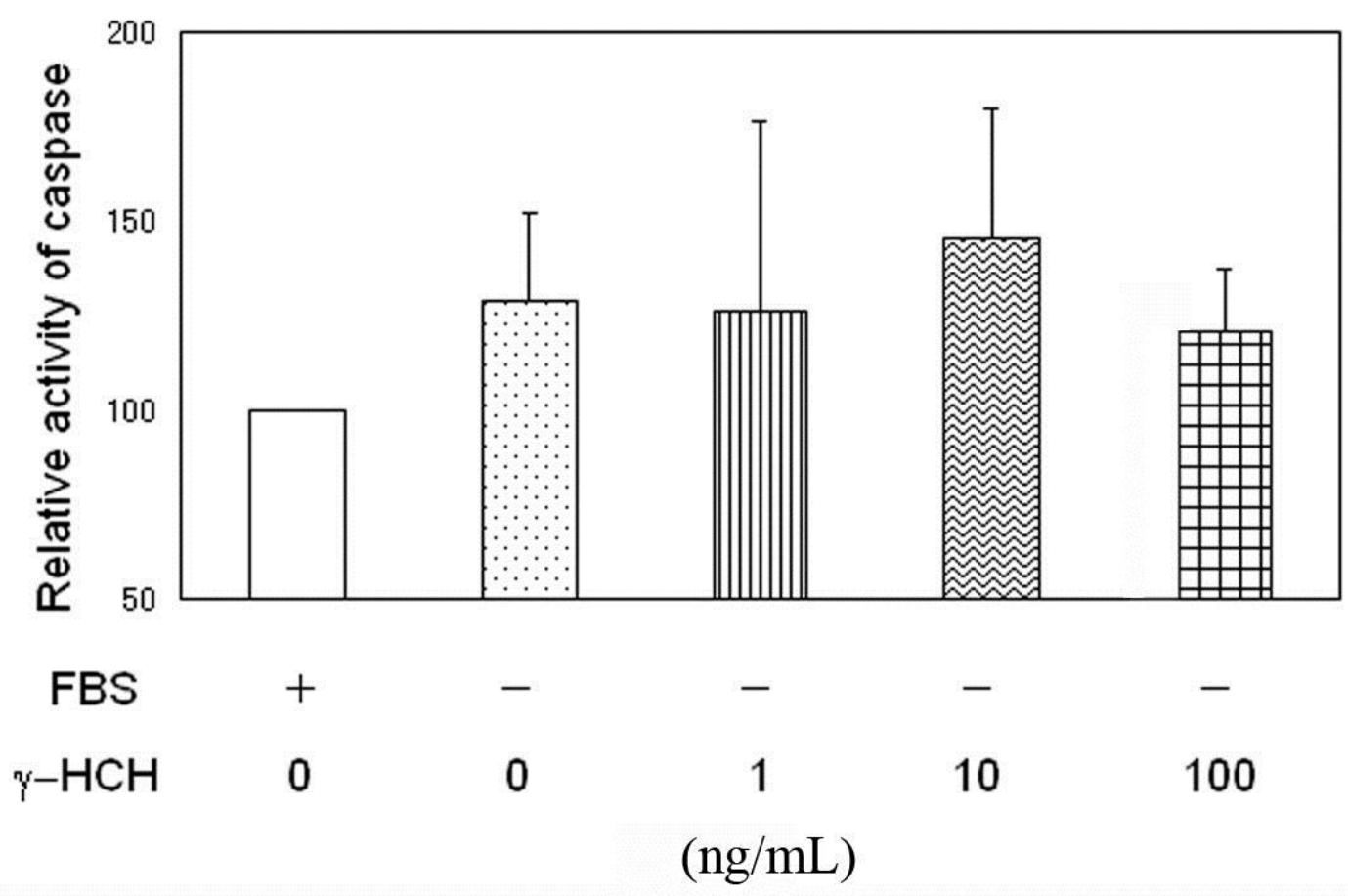

Fig.4 
Outline

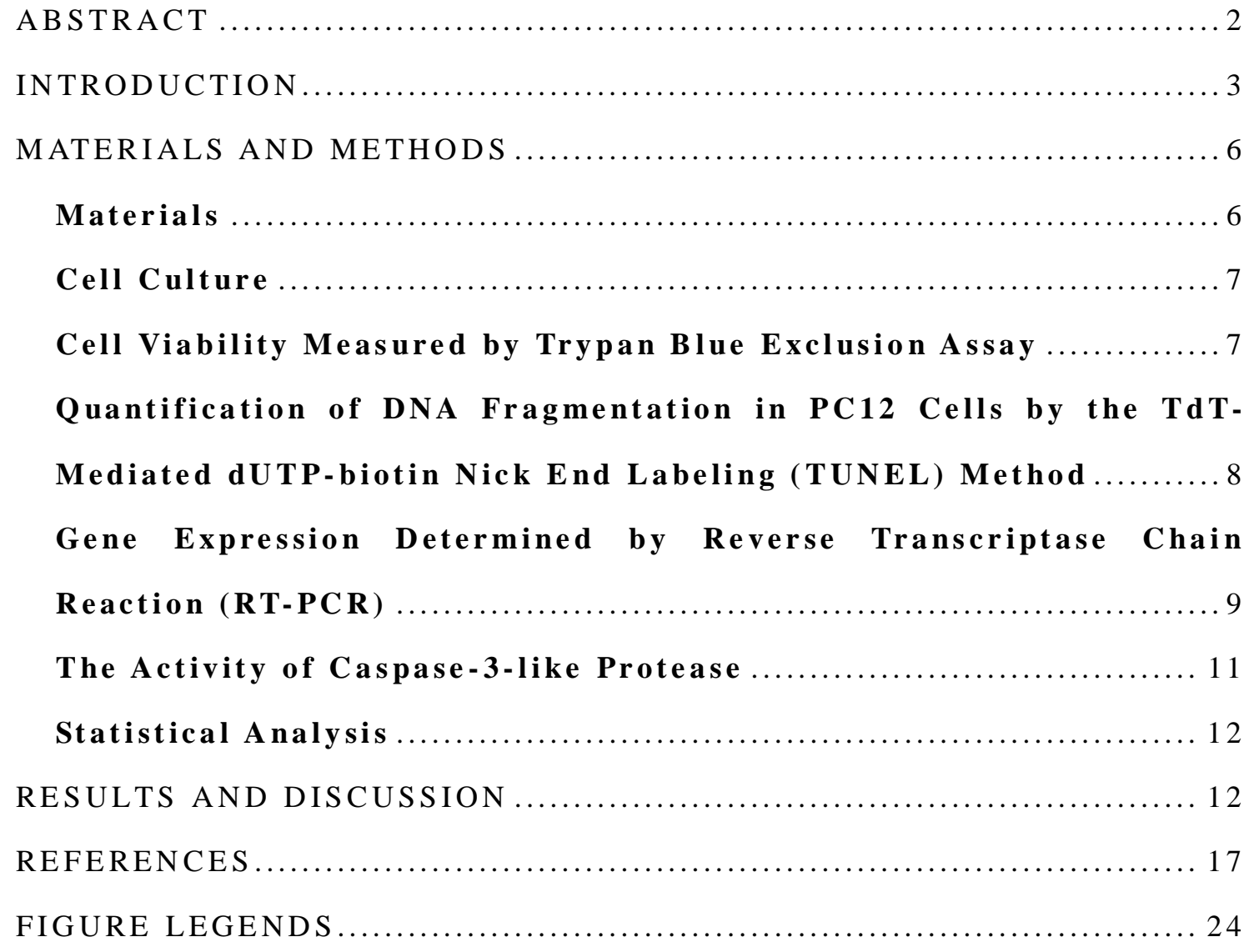

